\title{
Removal Effect of CODcr Ammonia Nitrogen and Total Nitrogen of Rural Domestic Wastewater in Southern China by $\mathrm{A}^{2} / \mathrm{O}^{2}$ Process
}

\author{
Li-qiang XU* \\ Pearl River Hydraulic Research Institute of PRWRC, \\ Guangzhou 510611, China \\ Key Laboratory of the Pearl River Estuarine Dynamics \\ and Associated Process Regulation, Ministry of Water \\ Resources, Guangzhou 510611, China \\ e-mail: xu_liqiang@163.com \\ Jiang-hua YU \\ School of Environmental Science and Engineering, \\ Nanjing University of Information Science and \\ Technology \\ Nanjing 210044, China \\ e-mail: yujh@nuist.edu.cn \\ Yuan-long ZHANG \\ Peal River Hydraulic Research Institute of PRWRC, \\ Guangzhou 510611, China \\ e-mail:659832454@qq.com
}

\author{
Hai-xia YU \\ Center for Water Resources and Environment, Sun Yat- \\ sen University, Guangzhou 510275, China \\ Key Laboratory of Water Cycle and Water Security in \\ Southern China of Guangdong High Education Institute, \\ Guangzhou 510275, China \\ e-mail: yuhaixia@mail.sysu.edu.cn
}

\author{
Huan LUO \\ Peal River Hydraulic Research Institute of PRWRC, \\ Guangzhou 510611, China \\ e-mail: gzluohuan@163.com
}

\begin{abstract}
Taking rural domestic wastewater in Southern China as the experimental object, the removal efficiency of CODcr, ammonia nitrogen and total nitrogen in different stages of the biofilm reactor and aeration conditions was studied by using the experimental simulation method in the $\mathrm{A}^{2} / \mathrm{O}^{2}$ process. The results showed that: First, this process is fast in biofilm culturing, but the removal efficiency of ammonia nitrogen and total nitrogen removal efficiency is not high. Biofilm culturing starts $17 \mathrm{~d}$ or so, the removal efficiency of CODcr can reach more than $80 \%$. Second, after the normal operation process, the removal efficiency of CODcr and ammonia nitrogen was stable by this device, CODcr average removal rate was $80 \%$, the average ammonia removal rate was $75 \%$, this process has good anti shock loading capability, and the device good stability. Third, in the process of $6 \mathrm{~h}$ and $2 \mathrm{~h}$ interval aeration conditions, ammonia removal efficiency was higher and more stable, had been able to reach in the "Urban Sewage Treatment Plant Pollutant Discharge Standard" level emission B standard for first class discharge standard, the removal efficiency of CODcr was better. Fourth, comprehensive energy consumption and removal efficiency, the best aeration conditions in this process was $6 \mathrm{~h}$ aeration and 2h interval. Operating under such conditions, the minimum cost per ton of sewage treatment. New sewage process $\mathrm{A}^{2} / \mathrm{O}^{2}$ biofilm reactor designed to deal with the rural domestic wastewater in Southern China, which is characterized by less land occupation, low energy consumption, high pollutant removal efficiency, nitrogen removal function very well, simple management, the effluent can meet the discharge standard.
\end{abstract}

Keywords- $A^{2} / O^{2}$ process; Domestic wastewater; CODcr, ammonia nitrogen and total nitrogen; Sediments; Removal effect

\section{INTRODUCTION}

In recent years, with the rural construction speed, the amount of sewage in rural areas will continue to increase, a large number of rural sewage directly discharged without treatment into rivers and lakes, causing serious pollution to the local water resources and the surrounding environment, and the change of water quality of traditional village life sewage and way of life, living standards and seasons related to water quality changes significantly ${ }^{[1]}$. Southern China rural area in mountainous and hilly, the laying of the sewage pipe network is difficult, resulting in rural sewage and waste water untreated or after simple treatment, directly discharged into the nearby waters, causing eutrophication. It is very necessary to centralized treatment of rural sewage and to control the discharge of water pollutants in rural areas. Looking for an economical and effective way of living sewage treatment is of great significance for the protection of the rural water environment.

$\mathrm{A} / \mathrm{O}$ process in wastewater treatment, the biological membrane technology is the combination of membrane technology and the traditional activated sludge treatment technology, its advantage is not only a removal rate, but also can effectively remove ammonia and other refractory materials; and the conventional aerobic biological treatment method compared with advantages of high sludge concentration, volume high load, sludge age of long and less 
land occupation ${ }^{[2]}$. Yang Jianzhong ${ }^{[3]}$ used a biological membrane as a biofilm reactor for treatment of domestic sewage to obtain a total nitrogen (TN) removal effect. Dong Bin ${ }^{[4]}$, in the study of activated sludge biofilm system for nitrogen and phosphorus removal affected by organic loading, found that the higher organic loading of sludge is beneficial to the removal of nitrogen and phosphorus from the reactor. The research shows that the system can achieve the best removal efficiency of organic pollutants only under the proper organic loading condition, and the organic load is an important parameter to characterize the ability of the reactor ${ }^{[5]}$.

Generally for urban sewage, the biofilm from the beginning to mature need for about $30 \mathrm{~d}$ under the conditions of $25^{0} \mathrm{C}^{[6]}$. The addition of activated sludge biofilm to ensure there is enough water when microorganisms can grow and adapt to the target environment of wastewater in this environment, and microorganisms in better attached biofilm carrier plate above, the start-up efficiency is higher ${ }^{[7]}$. But at the same time, there are also reports that the low $\mathrm{C} / \mathrm{N}$ ratio will inhibit the denitrification process, denitrification process requires organic carbon source as an electron donor, the lack of organic carbon source will inhibit denitrification, which affect the conversion of nitrogen ${ }^{[8]}$. Jia Yanping ${ }^{[9]}$ study found that higher COD load not only increases the cost of adding carbon source, but also inhibit the autotrophic nitrification bacteria growth, and reduce the removal efficiency of $\mathrm{NH}_{4}^{+}-\mathrm{N}$.

When the inlet velocity is constant, the reflux ratio is determined by the circulation speed. And the change of the circulation rate has great influence on the dissolved oxygen in the wastewater and the thickness and shear stress of the liquid phase layer when the wastewater flows through the biological membrane, which further affects the operation efficiency of the reactor ${ }^{[10-11]}$. If continue to increase the return ratio, not only increased the thickness and the influence of mass transfer of liquid layer, the hydraulic shear stress increases greatly, resulting in the biofilm is large and scattered off, directly influence the operation efficiency, and high reflux ratio to consume more capacity, mechanical damage probability will increase ${ }^{[11-12]}$.

Based on the existing biological treatment process, designed a set of $\mathrm{A}^{2} / \mathrm{O}^{2}$ technology of biological membrane reactor to rural sewage treatment in Southern China area, which is characterized by small footprint, low energy consumption, pollutant removal efficiency, high nitrogen removal function, simple management, the effluent can meet the discharge standard. The reactor biofilm culturing start-up, different pollutants removal efficiency and operation stability, different aeration conditions on the pollutant removal efficiency and energy consumption were studied, and the optimal operation conditions of the reactor were determined.

\section{MATERIALS AND METHODS}

\section{A. Materials}

The experimental device was made of stainless steel, the experimental device as shown in Figure 1, set the filter area, anaerobic zone, anoxic zone, primary aerobic zone and secondary aerobic zone, anaerobic zone and anoxic zone using activated sludge method, primary and secondary aerobic zone using compound biological treatment, aeration device were set at the bottom outlet baffle to prevent the loss of sludge. A mud bucket is arranged at the bottom of the aerobic area, and the sludge can be effectively collected. In order to prevent the device internal flow short flow, water holes of each reaction zone were on the diagonal arrangement. Each reaction zone at the bottom was vented, convenient cleaning device and the discharge of excess sludge.
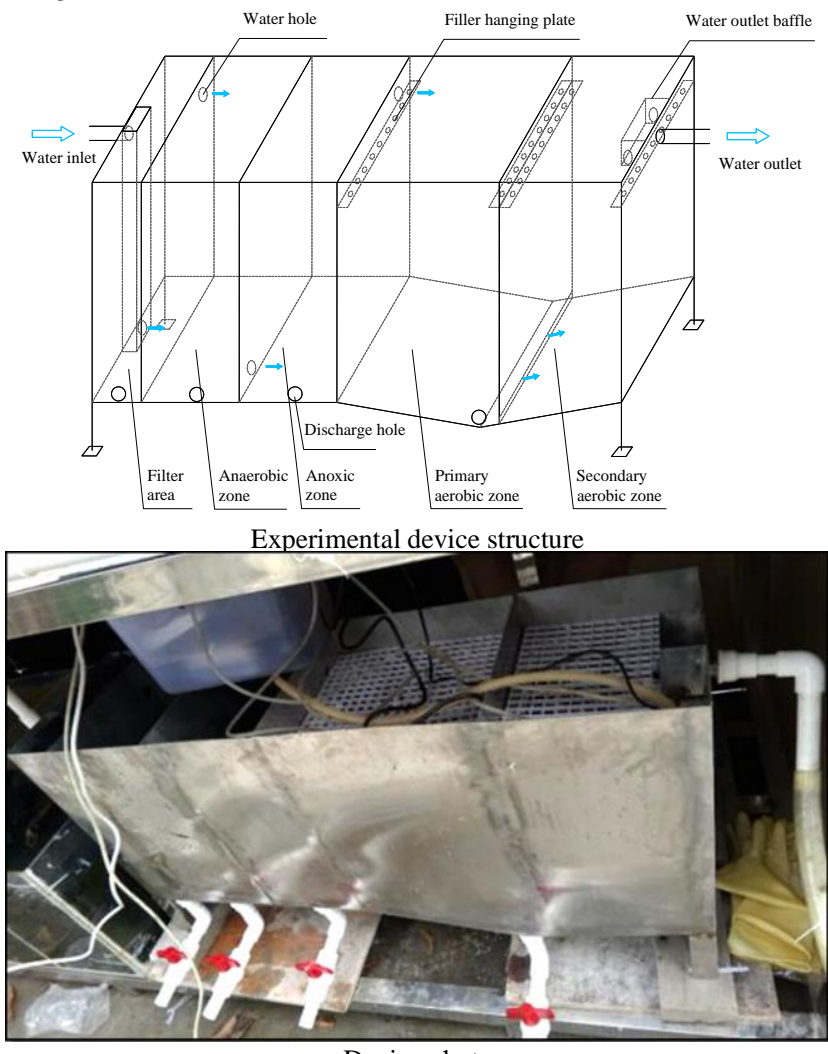

Device photo

Figure 1. Schematic diagram of experimental device structure and device real map

The experimental device covers an area of $0.44 \mathrm{~m}^{2}$, the design and treatment of sewage volume is $500 \mathrm{~L} \cdot \mathrm{d}^{-1}$. The parameters of the experimental device are shown in table 1.

TABLE I. SPECIFICATION PARAMETERS OF THE EXPERIMENTAL DEVICE

\begin{tabular}{lll}
\hline Parameters & $\begin{array}{l}\text { Size (length } \times \text { width } \times \\
\text { height })\end{array}$ & $\begin{array}{l}\text { Effective } \\
\text { volume }\end{array}$ \\
\hline Filter area & $35 \mathrm{~cm} \times 20 \mathrm{~cm} \times 40 \mathrm{~cm}$ & $23 \mathrm{~L}$ \\
Anaerobic zone & $35 \mathrm{~cm} \times 20 \mathrm{~cm} \times 40 \mathrm{~cm}$ & $23 \mathrm{~L}$ \\
Anoxic zone & $35 \mathrm{~cm} \times 20 \mathrm{~cm} \times 40 \mathrm{~cm}$ & $23 \mathrm{~L}$ \\
$\begin{array}{l}\text { Primary aerobic } \\
\text { zone }\end{array}$ & $35 \mathrm{~cm} \times 40 \mathrm{~cm} \times 40 \mathrm{~cm}$ & $40 \mathrm{~L}$ \\
$\begin{array}{l}\text { Secondary aerobic } \\
\text { zone }\end{array}$ & $35 \mathrm{~cm} \times 25 \mathrm{~cm} \times 40 \mathrm{~cm}$ & $27 \mathrm{~L}$ \\
Total & & \\
\hline
\end{tabular}


Aerobic filler with combined packing, the packing materials are composed of plastic ring, fiber wire, center line and supporting sleeve, as shown in Figure 2. Combined packing of silk fiber is floating in the water on the swing state, tow adhesion of microorganisms in water entrainment, strong ability to capture microorganisms. The technical parameters of combined packing are shown in table 2 .
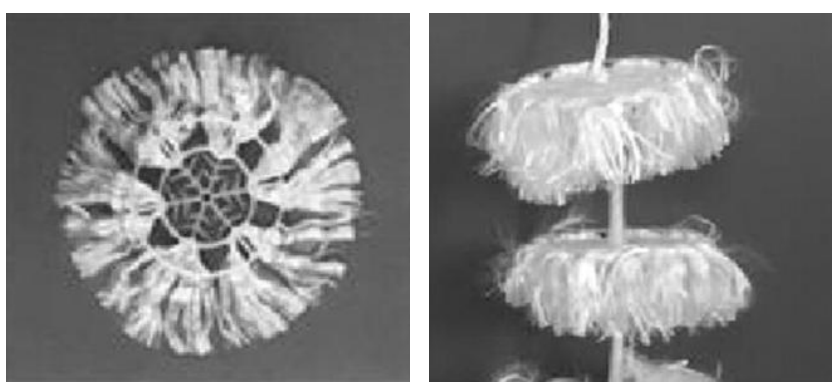

Figure 2. Combination packing photos

TABLE II. THE TECHNICAL PARAMETERS OF COMBINED PACKING

\begin{tabular}{lllll}
\hline Parameters & Ring plate & Fiber & Plastic ring diameter & Spacing of supporting sleeves \\
\hline Numerical Value & Plastic & Vinylon aldehyde silk & $80 \mathrm{~mm}$ & $150 \mathrm{~mm}$ \\
\hline
\end{tabular}

TABLE III. THE VALUE OF THE EXPERIMENT WATER QUALITY

\begin{tabular}{lllll}
\hline Parameters & $\mathrm{CODcr}\left(\mathrm{mg} \cdot \mathrm{L}^{-1}\right)$ & Ammonia nitrogen $\left(\mathrm{mg} \cdot \mathrm{L}^{-1}\right)$ & $\mathrm{TN}\left(\mathrm{mg} \cdot \mathrm{L}^{-1}\right)$ & $\mathrm{TP}\left(\mathrm{mg} \cdot \mathrm{L}^{-1}\right)$ \\
\hline Numerical Value & $300 \sim 400$ & $15 \sim 20$ & $20 \sim 30$ & $10 \sim 15$ \\
\hline
\end{tabular}

Domestic sewage for experiment was according to the actual needs of the experiment and the reference [13] configuration. Used rural domestic sewage in Southern China, after the dilution adjustment as the experimental raw water, the raw water quality parameters are shown in table 3 .

\section{B. Experiment methods}

The experiment is carried out in the experimental base of Lishui, the domestic sewage was pumped into the device by the pump, the experimental process is shown in Figure 3.

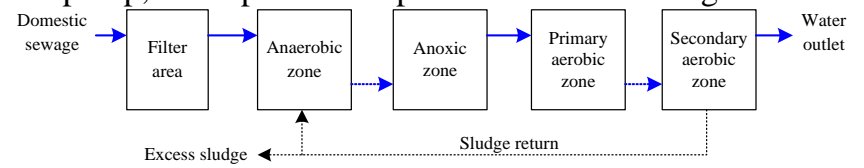

Figure 3. Experimental process flow chart

Startup method of $\mathrm{A}^{2} / \mathrm{O}^{2}$ process. Using the compound process, the normal operation of the device requires the synergistic action of activated sludge and biofilm in anaerobic and anoxic zones. The first stage of biofilm by short hydraulic retention time, increase the organic load, accelerate the growth of biofilm, when stable biofilm on the filler, adding inoculation acclimated activated sludge, activated sludge and biofilm interaction, cooperative symbiosis, achieve balance, while improving the hydraulic retention time, reduce the load, the nitrifying bacteria culture has become the dominant bacteria biofilm, thus completing the integration process of starting.

Process of $\mathbf{A}^{2} / \mathbf{O}^{2}$ startup process. This experiment was started in January 12, 2016. The starting process is as follows: [1] The reactor filled with water, adding the composite strain is about 5 grams, with exposure to $24 \mathrm{~h}$; [2] The control of dissolved oxygen concentration in aerobic zone was $2 \sim 4$ $\mathrm{mg} \cdot \mathrm{L}^{-1}$, the wastewater influent flow continuous influent 400 $\mathrm{mL} \cdot \mathrm{min}^{-1}$ control, run 13d; [3] The inoculation of activated sludge (Reflux sludge of sedimentation tank from Datansha sewage treatment plant), anaerobic zone and anoxic zone were injected into the $5 \mathrm{~L}$ sludge, aerobic zone sludge into $10 \mathrm{~L}$, water flow control for $200 \mathrm{~mL} \cdot \mathrm{min}-1$, the aerobic zone than the sludge back to the anaerobic zone to reflux, continuous operation.

Different aeration experiment scheme for $\mathrm{A}^{2} / \mathrm{O}^{2}$ process. The two groups of different aeration modes were set up to compare the effect of different aeration conditions on the removal efficiency of different pollutants, and the energy consumption of different aeration modes were investigated. The two aeration groups were as follows: aeration $6 \mathrm{~h}$ and $2 \mathrm{~h}$ interval, $2 \mathrm{~h}$ aeration and $2 \mathrm{~h}$ interval.

\section{Experiment items and analysis methods}

The whole experiment process is natural light outside the laboratory, the temperature is $16 \sim 25^{\circ} \mathrm{C}$. After the beginning of the experiment, the water sample was taken to measure CODcr, ammonia nitrogen and total nitrogen. The analysis methods are shown in Table 4.

\section{TABLE IV. EXPERIMENT ITEMS AND ANALYSIS METHODS}

\begin{tabular}{|c|c|c|}
\hline $\begin{array}{l}\text { Experiment } \\
\text { items }\end{array}$ & analysis methods & \\
\hline CODcr & Potassium dichromate method & \\
\hline $\begin{array}{l}\text { Ammonia } \\
\text { nitrogen }\end{array}$ & Nessler's reagent spectrophotometric method & \\
\hline Total nitrogen & $\begin{array}{l}\text { Potassium persulfate digestion } \\
\text { spectrophotometric method }\end{array}$ & UV \\
\hline
\end{tabular}




\section{RESULTS AND DISCUSSION}

\section{A. Biofilm Growth of Carrier And Pollutant Removal Efficiency in The Start-Up Stage}

\section{1) The Growth and Growth of Sludge Biofilm Start-up} Stage

Aerobic zone: the experimental operation of $7 \mathrm{~d}$ or so, can be observed in the filler of a clear pale yellow film like thick, after running $17 \mathrm{~d}$, the film on the packing of the thick material increased significantly, as shown in figure 4.
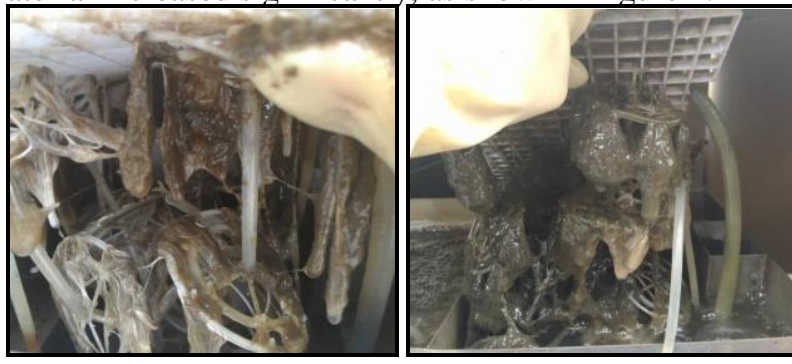

Run 7d, biofilm growth situation Run17d, biofilm growth situation

Figure 4. Growth of biofilm in start-up stage

Anoxic and anaerobic zone: the experimental operation is not obvious at the beginning of the operation, after running 7 $\mathrm{d}$, a small amount of air bubbles in the water surface of anoxic and anaerobic zone, the bubble is increased after running $17 \mathrm{~d}$, as shown in figure 5 .

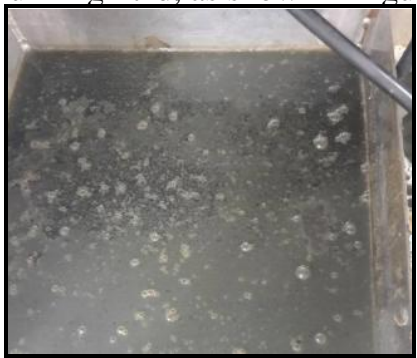

Run $7 \mathrm{~d}$ anaerobic zone situation Run $17 \mathrm{~d}$ anaerobic zone situation

Figure 5. Anaerobic reaction zone in start-up phase

\section{2) The Analysis of Pollutant Removal in the Start-Up} Phase

a) Removal Effect of CODcr in Start-Up Stage

During the start-up period, the removal of CODcr mainly depends on the filler surface biofilm of the aerobic zone. According to the experimental results, the removal of CODcr was lower in the start-up stage, and the sampling analysis was started after $7 \mathrm{~d}$ of the experiment.

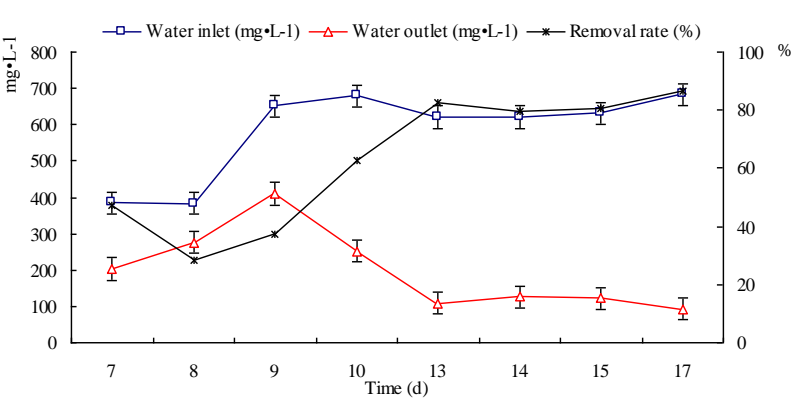

Figure 6. Removal effect of CODcr in start-up stage

As shown in figure 6, during start-up initial stage CODcr removal rate of the device is low, with the biofilm on the filler gradually thickened, CODcr removal efficiency also began to improve. Because of the suspended microorganism was less on the biofilm formation stage in aerobic zone, the concentration of sewage sludge is very low, so the removal rate of CODcr is only about $60 \%$. Start up $13 \mathrm{~d}$, there was rapid increase of sludge concentration after inoculation of activated sludge from sewage treatment plant, CODcr removal efficiency was significantly improved, the removal rate of CODcr after inoculation sludge was basically stable at more than $80 \%$.

\section{b) Removal Efficiency of Ammonia Nitrogen in the} Start-Up Stage

In the start phase of $17 \mathrm{~d}$, the removal efficiency of ammonia nitrogen was low. As shown in figure 7, at the beginning of the initial stage, the removal efficiency of ammonia nitrogen is not only low but also unstable. That is because of the early start, the hydraulic retention time was short, the suspension device states fewer microorganisms, anaerobic and anoxic device has no obvious effect, water erosion was strong led to part of the sludge water away, resulting in ammonia nitrogen removal effect was not stable. After inoculation of activated sludge, with the increase of biomass, the nitrification bacteria increased gradually, the nitrification rate of the plant was also increased, so the removal rate of ammonia nitrogen was increased to a certain extent. Because the running time was not long enough and the nitrification bacteria in the device was not enough, so the removal rate of ammonia nitrogen was lower than that of CODcr, and the removal rate of $17 \mathrm{~d}$ was about $60 \%$, and there was a trend of increasing.

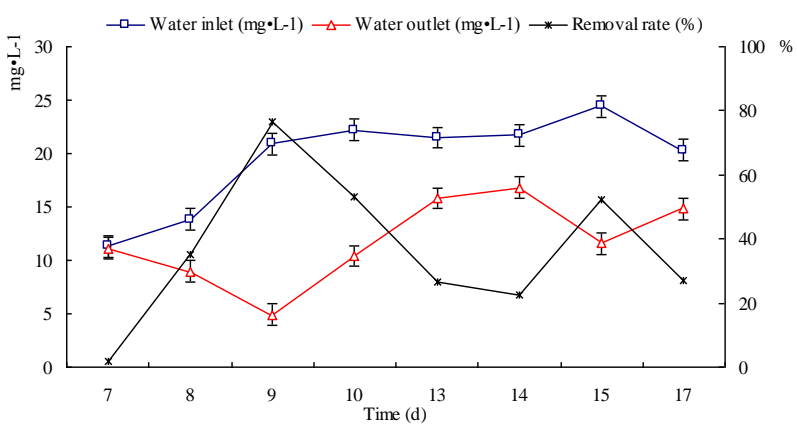

Figure 7. Removal effect of ammonia nitrogen in start-up stage 
c) Removal Efficiency of Total Nitrogen in the StartUp Stage

As shown in figure 8 , the experimental results show that the removal efficiency of total nitrogen is basically the same as that of ammonia nitrogen removal during the start-up phase. During start-up initial stage total nitrogen removal efficiency of the process was poor, mainly because of the start-up phase anaerobic and anoxic section of the heterotrophic denitrification bacteria quantity was less, the device can not effectively convert the nitrate nitrogen into nitrogen. With the increase of operation time, denitrifying bacteria gradually growth and reproduction, also mixed liquor from aerobic recirculation for denitrification to provide sufficient carbon source, the removal efficiency of total nitrogen device also increased gradually, in the process of starting the $17 \mathrm{~d}$ device, the total nitrogen removal rate reached about $60 \%$, had increased gradually the trend.

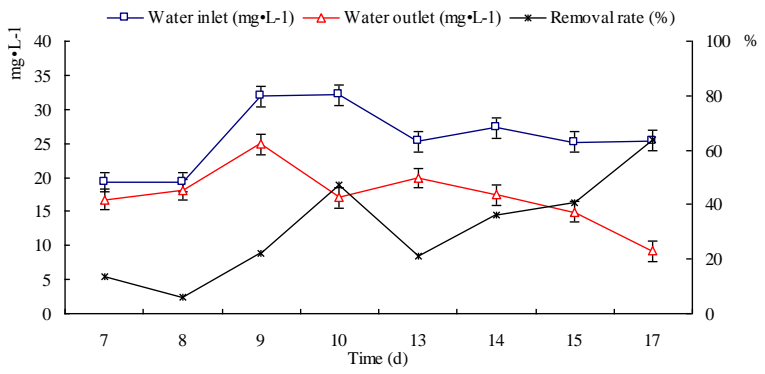

Figure 8. Removal effect of total nitrogen in the start-up stage

\section{B. Pollutant Removal Efficiency and Process Operation Stability During Operation}

1) The Removal Efficiency And Process Stability After The Success Of The Biofilm Of Pollutants

After running $17 \mathrm{~d}$, the removal rate of CODcr was above $80 \%$, the removal rate of ammonia nitrogen and total nitrogen was about $60 \%$, and showed a rising trend, hanging film basically achieved success. After the continuous operation of $25 \mathrm{~d}$, the water quality of the effluent was stable, and the pollutant removal rate has reached the best treatment effect, the difference of water quality in the water inlet area is great.

2) The Removal Effect And Stability Of The Codcr During The Operation

As shown in Figure 9, the CODcr removal rate during normal operation is stable at more than $80 \%$, up to about $85 \%$. Since February, the outdoor temperature was low, the reactor temperature was about $17{ }^{0} \mathrm{C}$, partially inhibited activity of microorganism, CODcr removal efficiency could not reach above $90 \%$. When the influent CODcr concentration of the device was from $350 \mathrm{mg} \cdot \mathrm{L}^{-1}$ to 450 $\mathrm{mg} \cdot \mathrm{L}^{-1}$, the removal efficiency of CODcr was still about $80 \%$, which shows that the process is better for the removal of CODcr.

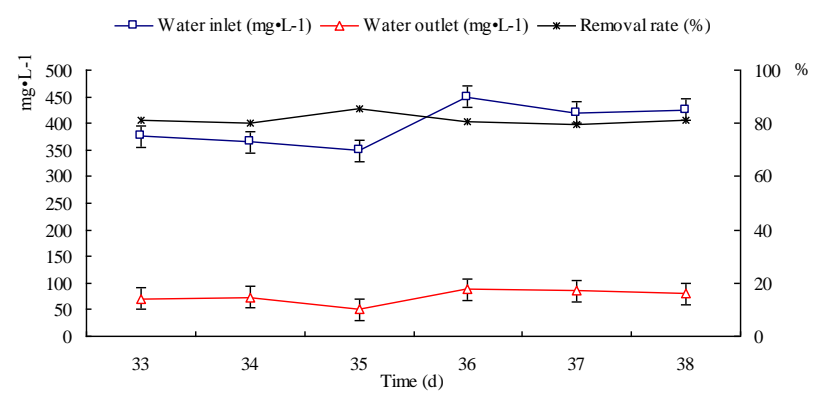

Figure 9. Removal effect of CODcr during operation

3) The Removal Effect And Stability Of The Ammonia Nitrogen During The Operation

As shown in Figure 10, the removal efficiency of ammonia nitrogen during operation is stable, maintained at about $75 \%$. Mainly because after a longer period of cultivation, the device of a large number of bacteria bred, while the set of aerobic partition also strengthened nitrification capacity of the device. During the operation, the ammonia nitrogen concentration changed from $15 \mathrm{mg} \cdot \mathrm{L}^{-1}$ to $25 \mathrm{mg} \cdot \mathrm{L}^{-1}$, and the removal efficiency of ammonia nitrogen was still relatively stable, so the process had a stable effect on the removal of ammonia nitrogen.

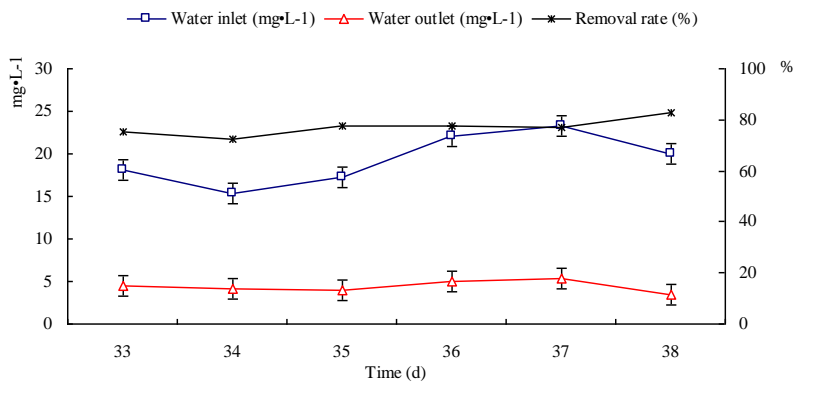

Figure 10. Removal effect of ammonia nitrogen during operation

\section{Removal Efficiency And Energy Consumption Of Pollutants Under Different Aeration Conditions}

Two different aeration modes were set up to compare the removal efficiency of different pollutants under different aeration conditions, and the energy consumption of different aeration modes was investigated.

1) The Removal Effect Of Pollutants Under Aeration 6h And Interval $2 h$ Condition

a) Removal Efficiency of CODcr

Figure 11 shows the scheme on the CODcr removal efficiency is not high, only about $50 \%$, this is because in the case of low inlet concentration data, while the CODcr removal efficiency is not high, but the effluent concentration has been maintained at $60 \mathrm{mg} \cdot \mathrm{L}^{-1}$, in accordance with the "urban sewage treatment plant emission standards" (GB18918-2002) the level B standard for first class discharge standard. Therefore, it can be considered that the 
removal efficiency of CODcr is better under the aeration condition.

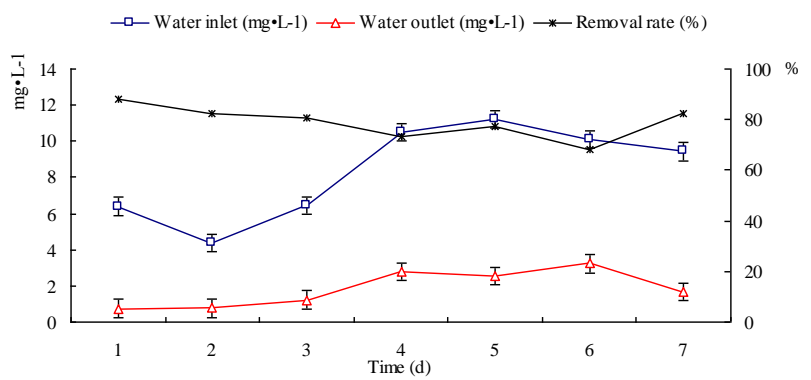

Figure 11. Effect of aeration $6 \mathrm{~h}$ and interval $2 \mathrm{~h}$ on the removal of CODcr

b) Removal Efficiency of Ammonia Nitrogen

Figure 12 shows that in the condition of aeration $6 \mathrm{~h}$ and interval $2 \mathrm{~h}$, the removal efficiency of ammonia device is maintained at about $80 \%$ and stable, indicating that this aeration is conducive to the nitrification of nitrobacteria, enables the device to maintain high removal efficiency.

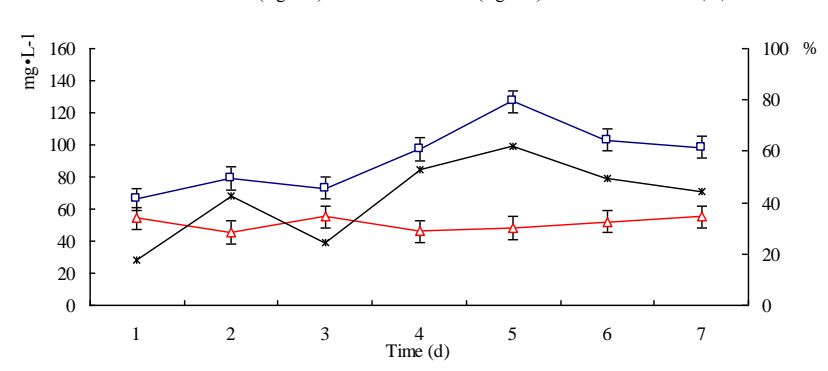

Figure 12. Effect of aeration $6 \mathrm{~h}$ and interval $2 \mathrm{~h}$ on removal of ammonia nitrogen

2) The Removal Effect of Pollutants Under Aeration $2 h$ And Interval $2 h$ Condition

a) Removal Efficiency of CODcr

As shown in Figure 13, after adjusting the aeration mode, before the $2 \mathrm{~d}$ CODcr removal efficiency decreased, the first $3 \mathrm{~d}$ removal efficiency began to pick up, and after $4 \mathrm{~d}$ CODcr removal was stable at about $90 \%$ and up to $96 \%$. The results show that the device can maintain a high CODcr removal efficiency under the condition of aeration $2 \mathrm{~h}$ and interval $2 \mathrm{~h}$.

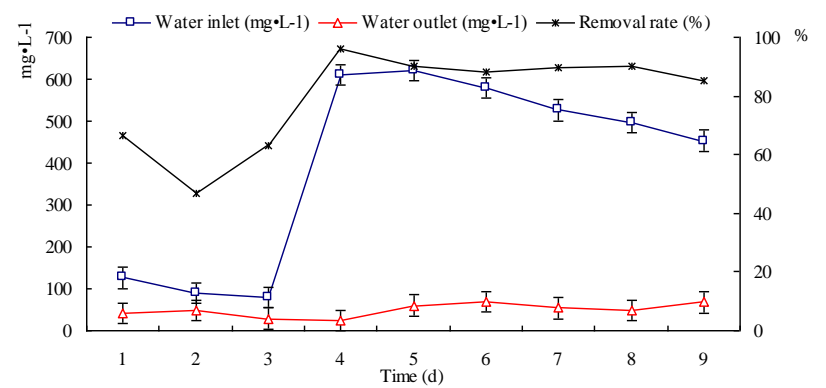

Figure 13. Effect of aeration $2 \mathrm{~h}$ and interval $2 \mathrm{~h}$ on the removal of CODcr

\section{b) Removal Efficiency of Ammonia Nitrogen}

As shown in Figure 14, the removal efficiency of ammonia nitrogen is not stable, the average removal rate is only about $60 \%$ under the condition of aeration $2 \mathrm{~h}$ and interval $2 \mathrm{~h}$. Under this scheme, the removal efficiency of ammonia nitrogen is poor.

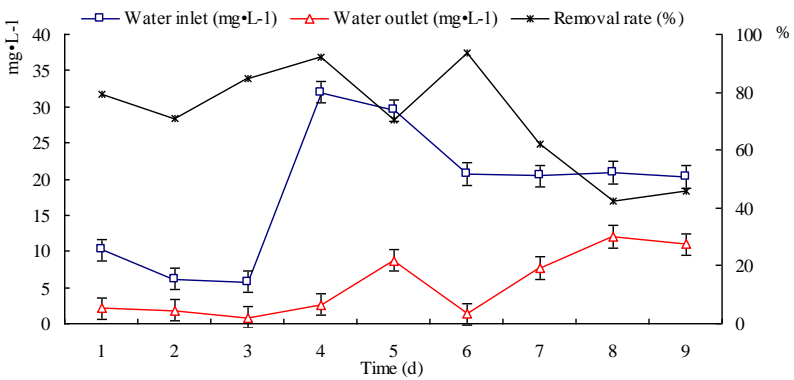

Figure 14. Effect of aeration $2 \mathrm{~h}$ and interval $2 \mathrm{~h}$ on removal of ammonia nitrogen

\section{3) The Energy Consumption and Operation Cost of} Different Aeration Conditions

Energy consumption and operating costs under different aeration conditions are shown in table 5. The equipment processing capacity of about $500 \mathrm{~L} \cdot \mathrm{d}^{-1}$, aeration fan by $50 \mathrm{~W}$, electricity prices by $0.68 \mathrm{RMB} \cdot \mathrm{kwh}^{-1}$. Comprehensive removal efficiency and stability, operation cost: The best aeration scheme for the experiment process is aeration $6 \mathrm{~h}$ and interval $2 \mathrm{~h}$. Under this aeration conditions, the operation cost is $0.61 \mathrm{RMB} \cdot \mathrm{kwh}^{-1}$, sewage treatment needs about 1.22 $\mathrm{RMB} \bullet \mathrm{t}^{-1}$.

TABLE V. COMPARISON OF DIFFERENT AERATION MODES.

\begin{tabular}{|c|c|c|c|c|}
\hline $\begin{array}{l}\text { Serial } \\
\text { number }\end{array}$ & $\begin{array}{l}\text { Aeration } \\
\text { method }\end{array}$ & $\begin{array}{l}\text { Removal effect } \\
\text { of CODcr }\end{array}$ & $\begin{array}{l}\text { Removal } \\
\text { effect of } \\
\text { ammonia } \\
\text { nitrogen }\end{array}$ & $\begin{array}{l}\text { Cost of } \\
\text { operation }\end{array}$ \\
\hline 1 & $\begin{array}{l}\text { Continuous } \\
\text { aeration }\end{array}$ & $\begin{array}{l}\text { The average } \\
\text { removal rate of } \\
80 \% \text {, the } \\
\text { removal effect } \\
\text { is stable }\end{array}$ & $\begin{array}{l}\text { The average } \\
\text { removal rate } \\
\text { of } 75 \% \text {, the } \\
\text { removal } \\
\text { effect is } \\
\text { stable }\end{array}$ & $\begin{array}{l}0.82 \\
\mathrm{RMB} \bullet \mathrm{d}^{-} \\
1, \quad 1.63 \\
\text { RMB•t } \\
\text { sewage }\end{array}$ \\
\hline 2 & $\begin{array}{l}\text { Aeration } \\
6 \mathrm{~h} \text {, interval } \\
2 \mathrm{~h}\end{array}$ & $\begin{array}{l}\text { Removal effect } \\
\text { is stable, stable } \\
\text { up to the } \\
\text { standard }\end{array}$ & $\begin{array}{l}\text { The average } \\
\text { removal rate } \\
\text { of } 80 \% \text {, the } \\
\text { removal } \\
\text { effect is } \\
\text { stable }\end{array}$ & $\begin{array}{l}0.61 \\
\mathrm{RMB} \bullet \mathrm{d}^{-} \\
1, \quad 1.22 \\
\mathrm{RMB} \bullet \mathrm{t}^{-1} \\
\text { sewage }\end{array}$ \\
\hline 3 & $\begin{array}{l}\text { Aeration } \\
2 \mathrm{~h} \text {, interval } \\
2 \mathrm{~h}\end{array}$ & $\begin{array}{l}\text { The average } \\
\text { removal rate of } \\
90 \% \text {, relatively } \\
\text { stable }\end{array}$ & $\begin{array}{l}\text { The average } \\
\text { removal rate } \\
\text { of } 60 \% \text {, less } \\
\text { stable }\end{array}$ & $\begin{array}{l}0.41 \\
\mathrm{RMB} \cdot \mathrm{d}^{-} \\
1, \quad 0.82 \\
\mathrm{RMB} \cdot \mathrm{t}^{-1} \\
\text { sewage }\end{array}$ \\
\hline
\end{tabular}

\section{CONCLUSION}

(1) The start-up speed of this process is basically the same as that of the traditional biological contact oxidation film, and the film start-up was fast. During the start-up process, the growth of the bacteria and the denitrification 
bacteria was slow, which showed that the removal efficiency of ammonia nitrogen and total nitrogen removal efficiency was not high. Film start up $17 \mathrm{~d}$ or so, the device on the removal efficiency of CODcr can reach more than $80 \%$. But at this time the treatment effect was not stable, still need some time to run to make the device within the microbial growth to achieve stability.

(2) After the normal operation of the process, the removal efficiency of CODcr and ammonia nitrogen was stable. The average removal rate of CODcr was $80 \%$ and the average removal rate of ammonia nitrogen was $75 \%$. Normal operation of CODcr and ammonia nitrogen efficiency was not high, mainly by the impact of temperature, lower temperature inhibited the activity of some microorganisms. From the impact of inlet concentration changes, either CODcr or ammonia nitrogen removal efficiency can be maintained at a relatively stable level, indicating that this process has better anti shock loading capability and good stability of the device.

(3) Under the condition of aeration $6 \mathrm{~h}$ and interval $2 \mathrm{~h}$, the removal efficiency of ammonia nitrogen was higher and more stable. Can be achieved in the "urban sewage treatment plant pollutant emission standards"(GB18918-2002) the level B standard for first class discharge standard., the device on the CODcr removal efficiency was better. Under the condition of aeration $6 \mathrm{~h}$ and interval $2 \mathrm{~h}$, CODcr removal efficiency was higher and about $90 \%$, but the removal efficiency of ammonia nitrogen was not stable, the removal efficiency was only about $60 \%$. Because of the decrease of aeration rate, the nitrification of nitrification bacteria in the device was affected, and the removal efficiency of ammonia nitrogen was low.

(4) Comprehensive removal efficiency and stability, operation cost: The best aeration scheme for the experiment process is aeration $6 \mathrm{~h}$ and interval $2 \mathrm{~h}$. Under this aeration conditions, the operation cost need the lowest cost per ton of sewage.

New sewage process $\mathrm{A}^{2} / \mathrm{O}^{2}$ biofilm reactor designed to deal with the rural domestic wastewater in Southern China, which is characterized by less land occupation, low energy consumption, high pollutant removal efficiency, nitrogen removal function very well, simple management, the effluent can meet the discharge standard.

\section{ACKNOWLEDGMENT}

The data of this study was provided by the National Natural Science Foundation of China (Grant No.: 41301627,
Grant No.: 41401546). And the preparation of this paper was funded by the Natural Science Foundation of Guangdong Province, China (Grant No.: 2015A030313866) and the Science and Technology Innovative Project of Water Resources of Guangdong Province, China (Grant No.: 201412)

\section{REFERENCES}

[1] WANG Li-li, LI Yan-Ju, YUAN Cong-ying, et al. Temporal change of water quality of the typical rural domestic sewage in Chaohu Lake basin[J]. Environmental Chemistry, 2012, 31(7):998-1002. In Chinese.

[2] BEAUCHEMIN M. A density-based similarity matrix construction for spectral clustering [J]. Neurocomputing, 2015, 151:835-844.

[3] YANG Jian-zhong, LIU Yi-hui, ZHANG Xing-wen, et al. Treatment of oil-refining wastewater by membrane biological reactor[J]. Technology of Water Treatment, 2005, 31(11):64-66. In Chinese.

[4] DONG Bin, LIANG Ya, ZHOU Zeng-yan, et al. Influence of high organic load on nitrogen and phosphorus removal in an activated sludge-biofilm combined system[J]. Journal of TongJi University (Natural Science), 2006, 34(8):1066-1069. In Chinese.

[5] LIU Hong-bo, YANG Chang-zhu, PU Wen-hong, et al. Effect of organic loading rate on granular SBR[J]. Environmental Science, 2009, 30(5):1450-1452. In Chinese.

[6] WANG Li-li, LU Chuang-xin, JIN La-hua. Research on start-up of suspended bio-film process for stream treatment [J]. Journal of Jinan University (Natural Science), 2008, 29(1):73-76. In Chinese.

[7] DI BELLA G, DURANTE F, TORREGROSSA M, et al. Start-up with or without inoculum? analysis of an SMBR pilot plant [J]. Desalination, 2010, 260(1/2/3):79-90.

[8] TAN Chong, LIU Ying-Jie, WANG Wei, et al. Effect of carbon /nitrogen ratio on short-cut nitrification and denitrification of polyurethane biofilm reactor[J]. Environmental Science, 2014, 35(10):3807-3813. In Chinese.

[9] JIA Yan-ping, ZHANG Lan-he, WANG Shan-shan. Effect of carbonto-nitrogen mass ratio and ammonium nitrogen loading rate on simultaneous nitrification and denitrification by using sequencing batch reactor[J].Chemical Engineering, 2012, 40(5):6-10. In Chinese.

[10] ORANDI S,LEWIS D M,MOHEIMANI N R. Biofilm establishment and heavy metal removal capacity of an indigenous mining algalmicrobial consortium in a photorotating biological contactor[J] Journal of Industrial Microbiology and Biotechnology, 2012, 39(9):1321-1331.

[11] HASSARD F, BIDDLE J, CARTMELL E, et al. Rotating biological contactors for wastewater treatment-a review[J]. Process Safety and Environmental Protection, 2015, 94:285-306.

[12] TANG Yun-lu, LIU Dong-fang, YU Jie, et al. Packed rotating biological contactor system for treatment of simulated organic wastewater[J]. Chinese Journal of Environmental Engineering, 2013 7(6):2121-2126. In Chinese.

[13] ZOU Jun-liang, YANG Jing-ping, Lü Ya-min. Aquaculture wastewater treatment using a moving bed biofilm reactor(MBBR)[J]. Acta Scientiae Circumstantiae, 2013, 33(12):3220-3226. In Chinese. 